\title{
A Review of Microgrid-Based Approach to Rural Electrification in South Africa: Architecture and Policy Framework
}

\author{
Vinny Motjoadi, Pitshou N. Bokoro* $*$ and Moses O. Onibonoje \\ Department of Electrical and Electronic Engineering Technology, University of Johannesburg, \\ Doornfontein 2028, South Africa; 802037057@student.uj.ac.za (V.M.); femi_onibonoje@yahoo.com (M.O.O.) \\ * Correspondence: pitshoub@uj.ac.za; Tel.: +27-11-559-6114
}

Received: 29 March 2020; Accepted: 19 April 2020; Published: 2 May 2020

\begin{abstract}
Access to electricity for every South African citizen, including rural dwellers, is a human right issue guaranteed by the government's laws and policies. However, many remote rural areas still suffer from a lack of this very important amenity, due to the expensive prospect of connecting them to the central national grid. The feasible approach to connecting the rural communities to electricity supply is suggestively through the use of microgrid solutions. The microgrid technology is a very recent and viable option for the energy revolution. Microgrids result from the incorporation of energy storage systems, distributed generators, and localized loads. The application of this technology requires deliberate and extensive work on the operational architecture and the policy framework to be adopted. The energy storage devices form an integral part of the microgrid configuration or architecture to make sure more maintainable and constant operation is attained. This paper presents a review of the architectures of the existing microgrid systems, as well as the policy framework for implementable solutions. The various architectures display the peculiarity of the systems based on the increased grid performance, stability, quality of electricity, and other comparative advantages. The microgrid architectures are fundamentally recognized according to their AC, DC, or hybrid distribution buses and the complexity inherent to them. In the Policy And Development Section, the problems are treated as 'a search for the truth' - a truth being revealed by close and objective examination. The core of the problem to be solved is revealed clearly, thereby giving the basis for simplifying and solving it. The policies encourage the accomplishment of a zero-carbon dioxide $\left(\mathrm{CO}_{2}\right)$ emissions, energy security attainment, the meeting of the electricity demand, and, lastly, the promotion of access to electricity in rural areas. It is established that the returns through charges of the consumers are very insignificant. Although returns on investment always come in conflict with the human right demands of the local indigenes, the policy framework would be explicit on the mode of returns for the government, private partners, and the communities-a return that can be short, medium, or long term. Policymakers would be keen on the exhaustive analysis of issues, leading to optimal decision making.
\end{abstract}

Keywords: microgrids; energy demand; policy framework; grid architecture; distributed generation; energy storage systems

\section{Introduction}

Most remote rural communities in South Africa (SA) do not have access to electricity. The South African Government (SAG) provides energy to her citizens and inhabitants as a fundamental right, through power supply from a central national grid. All the main cities and the remote rural areas have a common right of access to electricity. However, rural communities are located at distances apart 
and far away from the central grid. Hence, the provision of energy for the various communities via the connection to the grid becomes economically unviable, in terms of energy quality, cost, security, and loss. Meanwhile, the immediate returns on investment in these areas are insignificant and almost nothing because charges through electricity tariffs from the consumers are extremely low. The main purpose of electricity for rural dwellers is domestic use, and electricity affordability remains a challenge. The SAG must intervene in making access to electricity possible in a customized form to meet the consumers' needs and their capacity to pay [1]. The conventional centralized grids continue to experience struggles with issues such as reliability, stability, sustainability, power quality, and efficiency [2,3]. The conventional energy distribution mode in South Africa significantly consists of coal and nuclear plants, which are located far away from remote rural communities thereby making power distribution cost very high [4]. However, grid extension is not sustainable in providing electricity to remote rural communities. A decentralized approach of microgrid solutions is a viable alternative for providing the required energy demand with the right policy framework for support. The high cost of extending grid to remote SA communities and other developing nations with little or no economic activity has increasingly made the microgrid approach an attractive measure to solve the problem of energy provision $[2,3]$. The brand of energy technology provides improvement for the living standard of rural dwellers. In addition, it positively impacts the social strata of the communities through local content harmonization and encouragement of feasible and efficient energy systems. According to Akinbulire et al. [5], the envisaged decentralized approach is researched and established to be economically viable for remote communities. In 2008, the World Bank reiterated that grid extension is mainly viable as an alternative for urban electrification and about $28 \%$ for the remote communities. The further focus is the system viability for power supply to the majority $(72 \%)$ of the remaining rural communities. Therefore, the use of stand-alone grids or microgrids is regarded as an alternative solution with the need for appropriate architecture and policy formation relating to funding models. With the right models and policy frameworks, renewable energy-powered microgrids will provide electricity for a larger rural population at a very low cost in comparison to the required cost for the conventional generators [6,7].

Microgrids are interconnections of power generators, storage devices, and the distribution equipment to make power available to selected isolated consumers. The number of target consumers differentiates the sizes of the grids, whether to be referred to as "micro or mini" grids. Microgrids rate at about $160-700 \mathrm{~kW}$ while the mini-grids have power generation ranging from 5 to $12 \mathrm{~kW}$. Microgrids are designed for isolated operation, or rarely through connections to the national utility facilities [8-11]. Microgrids have been considered as preferred alternatives to the weakening conventional energy distribution structure, especially in supplying modular consumers. Microgrids can operate as well-adjusted electricity cells in the current supply grids or as standalone electricity systems for small populations. A microgrid has the capacity of providing platforms for easily-adaptable power system networks within the existing centralized grid during planning programs for the network expansion. Microgrids provide distinctive competitive benefits to consumers and advance considerable advantages within the entire energy chain. The utility grid has presented an opportunity to unearth microgrid as a way out to upcoming electrical network problems, namely forever growing electrical demand, collecting energy from renewable energy sources, guaranteeing power consistency, and power quality. The system provides interventions, which include increased energy utilization, enhanced energy proficiency, reduced environmental impression (reduction in $\mathrm{CO}_{2}$ emissions), improved power supply reliability, increased grid capacity, clog support, improved grid safety, and more cost-effective energy configuration substitution [12,13].

The majority of the power projects in the country are composed of either coal or nuclear generation plants and are built and managed by SAG institutions. Renewable energy (RE)-based microgrids are becoming more popular and adaptable with the incorporation of distributed generations. Across many nations, investors are leveraging the decreasing cost of RE technologies, along with the discouraging very high cost of fuel-powered plants, to focus investments in the area of microgrids [14]. Some 
countries have made remarkable progress in the establishment of microgrids and mini-grids. China has approximately 22,000 microgrid projects. In addition, Vietnam, India, Nepal, and Sri-Lanka each have 50-700 microgrids projects [15]. Despite the benefits of microgrids and the improvement they provide for electricity access, the rate of adoption is still low in many developing countries. The causes of the low adoption and implementation could be attributed to economic, socio-political, and technical issues. Access to the required funds is a major barrier in the implementation of the result-oriented systems in rural communities [6,16]. A very huge upfront investment cost is predictably incurred in implementing microgrids for the remote areas, and the returns on such investment are expectedly very low from the target market. The initial capital for setting up such systems is predictably greater than the required capital for commensurate diesel-powered generators [14].

Access to electricity in South Africa by both modern cities and rural dwellers is a common human right issue. However, the absence of economic activity in remote rural communities makes returns on investment through charges of the consumers very insignificant. A robust government policy framework is needed and influential to ensuring the required attraction for future investment in microgrids for rural dwellers in South Africa. A framework to facilitate the most suitable business model for developing the best schemes for providing electricity for the communities. In addition, it enables small-scale and localized architecture that will make the management of the equipment easier and consequently minimize the possible technical and non-technical losses of the existing network. The improved reliability will lower the total cost when considered as a long-term facility, aided by the partnership of government, private investors, and the communities [13].

This paper reviews the details of the existing architectures of microgrid systems and the policy framework for implementing feasible power supply solutions to SA remote rural communities. It provides an extensive discussion of the various microgrid architectures and highlights the peculiarity of the systems based on the increased grid performance, stability, quality of electricity, and other comparative advantages. The paper also discusses the needed policy framework that meets the electricity demand and quality. A framework that ensures a balance between the human right demand for access to electricity by the consumers and the possibility of returns on investments in energy provision by the government, private partners, and the communities-a return that can be short, medium, or long term. The remaining part of the paper is structured as follows. Section 2 reviews the existing electricity supply in South Africa. Section 3 reviews the various architectures of microgrid systems. Section 4 discusses the policy framework for the implementable microgrid systems. Section 5 concludes the paper.

\section{Existing Electricity Supply Chain in South Africa}

South African energy is mainly generated from coal with about $59 \%$ of its total primary energy capacity. The other local sources of energy in South Africa include natural gas, hydropower, biomass, nuclear, solar, and wind power, as shown in Figure 1. The country has an abundance of coal in the eastern region, known as Mpumalanga province, which thus explains why most of the power plants are located in the area [17]. The energy outputs from the various plants are harnessed into a centralized grid from which every part of the country is being supplied with electricity [18]. The SA coal supplies are plenty and cheap, thereby enabling energy costs in the country to be very low. However, the present dependence on coal-fired power plants makes SA one of the countries with the highest $\mathrm{CO}_{2}$ emissions, which contribute to climate changes. The increasing population in the South African cities and the energy demands in the rural communities continuously dictate the need for expansion in the supply capacity of the energy sector. In addition, it is imperative to ensure optimal use of resources, energy security, and common access across the board $[17,19,20]$. 


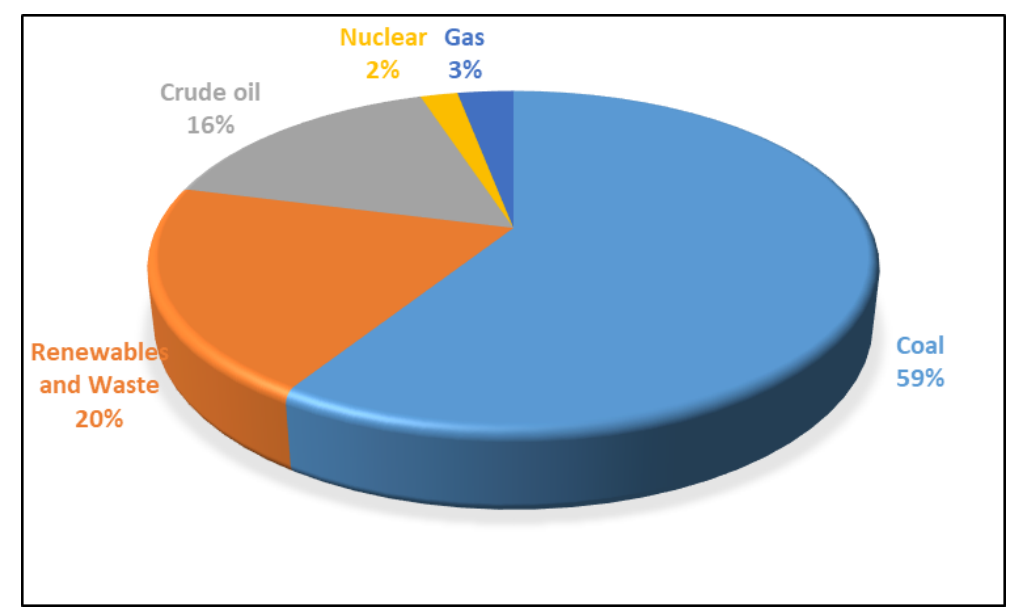

Figure 1. Primary energy supply in South Africa.

Electricity supply in SA is vertically integrated with Eskom, the only power transmission licensed company. The power distribution responsibility is shared among Eskom, the municipalities, and some other licensed distributors. The SA electricity end-users are categorized as agriculture $(2.6 \%)$, industrial (37.7\%), domestic (17.2\%), mining (15\%), transport $(2.6 \%)$, commercial $(12.6 \%)$, and general $(12.3 \%)$. In the SAG gazette No. 31741 of 2008, the major objectives in the electricity sector include non-discriminatory and open access to the transmission system, increased social equity to cater for the low-income earners, improved competitiveness and efficiency for the provision of high-quality and low-income inputs in all sectors, sustainable and environmentally-friendly short- and long-term exploration of the natural resources, private sector partnership and participation in the energy industry, and the right of choice for electricity supply $[17,18,21]$.

Demand for electricity is being influenced by different factors, among which are: output or economic production growth, electricity tariff, weather pattern, population growth, and changes in technology. Price and income remain the fundamental drivers for electricity demand at the macroeconomic level [22]. Eskom generates about $95 \%$ of the consumed electricity in South Africa. Therefore, as indicated in Figure 2, Eskom can transpose the national electricity demand in SA from the historical trend in the annual sales. The data represent the annual financial period of Eskom, with a change in the financial year in 2004, thereby making the financial year in 2005 to represent 15 months of data. Meanwhile, the overview of maximum demand data can help to identify possible risks. Whenever there is a small margin between the measured and the notified maximum demand, there is a risk of a consumer exceeding the notified maximum demand. On the contrary, prospective opportunities can be harnessed in reducing the cost of the notified maximum demand whenever the margin of difference is relatively large. The maximum demand margin can be calculated using Equation (1) [23]:

$$
M D_{\text {margin }}=\left[1-\frac{\sum_{i=1}^{12} M D_{i}}{\sum_{i=1}^{12} N M D_{i}}\right] \times 100
$$

where $M D_{i}$ is the measured demand (maximum) for month $i$ in $\mathrm{kVA}$ and $N M D_{i}$ is the notified demand (maximum) for month $i$ in $\mathrm{kVA}$.

A major electricity objective of the SAG before 2025 is to increase the energy end-use for the residential sector to $97 \%$ of official households. In South Africa, $31 \%$ of the inhabitants reside in remote rural areas. About $95 \%$ of rural dwellers are minimum wage earners with a lack of accessibility to reliable electricity. The SAG's commitment towards rural electrification is being impeded by the centralized nature of the electricity grid, the capital-intensive means of extending the existing power infrastructure, and the near-zero returns on investment due to no economic activities in the areas. Eskom states that usage of electricity in remote rural communities is minimal and subsequently impossible to recover operation and capital cost from charges alone from those areas. Therefore, 
the SAG (through Eskom) faces a complex problem of increased electricity demand and difficult diversification of energy production capability, resulting in considerable blackouts, load-shedding, power unreliability, instability, and low power quality in many parts of the country for both rural and urban areas [24-26].

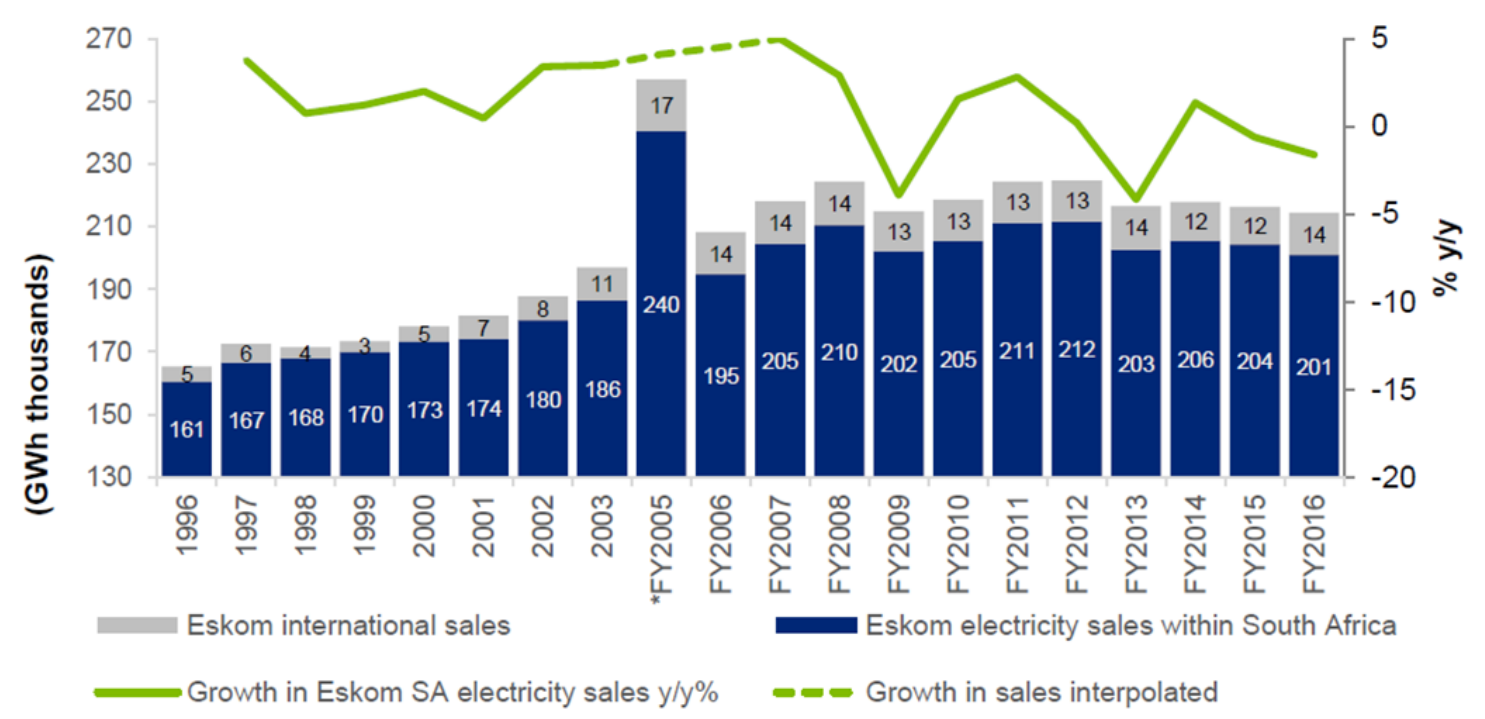

Figure 2. Historical trend of South Africa's electricity sales by Eskom between 1996 and 2016 [22].

Presently, the SAG is utilizing both grid and off-grid connected alternatives for rural area electrification. The off-grid alternative (50 W Solar Home Systems (SHS)), a cheaper and easier electricity generation, is supplied per household where the centralized grid connection is isolated. However, the off-grid electricity supply is limited to domestic applications. It does not provide scope for job creation, boosting of economic activities in the communities, or promoting rural development for future economic planning. The solar energy alternative has the greatest potential to address the need for access to electricity in remote rural communities with adequate increased localization. The electricity has several forms of supply, which can meet or surpass the electrical energy needs of remote rural communities with reasonable reliability [27]. In addition, various studies have suggested other alternative approaches to providing electricity access such as hybrid and stand-alone photovoltaic (PV) system, wind turbines, diesel generators, and microgrids. The electricity supply alternatives are utilized with energy storage, excluding main grid connections [28,29]. Meanwhile, researchers have established a grid decentralization solution as a very reliable approach to providing electricity access to remotely scattered rural communities. The approach is well harnessed and implementable in an efficient microgrid system for alternative power solutions to the different rural locations in South Africa. By taking the advantage of the renewable energy regime of SAG, a preferred PV solar microgrid system architecture can be adopted, with a suitable policy framework formulated, to expand electricity access to the rural communities of South Africa.

\section{Architecture and Control Strategies of Microgrid Systems}

Microgrids consist of a generalized collection of interrelated electrical loads and distributed energy resources which are operative in both grid-connected or island mode [30]. Microgrid being defined according to the United States (US) Department of Energy (DOE) is determined as a set of intertwined loads and integrated or distributed electricity resources (DERs) within explicitly characterized system-controlled electrical boundaries [31]. Microgrids are limited, modernized, small scale grids, contrary to the normal centralized power network (macrogrids) [27,32]. Microgrids are playing a key role in expanding access to electricity to remote rural communities. The limitations and insufficiencies of the utility grid are overpowered by microgrid application and control. Microgrid 
systems have been applied and used in remote rural communities of countries such as the United States of America (USA), the United Kingdom (UK), Canada, Kenya, and South Africa [33]. Currently, there is an increase of awareness for clean, consistent, and inexpensive energy generation, which is shifting the existent energy predicament for reliance. The current ageing utility grid infrastructure is at risk due to high accumulative energy demand; it requires cost-effective and integrated solutions [12]. Meanwhile, microgrids could be powered conveniently by clean renewable energy sources. In addition, microgrids have the ability to detach from the utility grid and function alone, sustain system adaptability or resilience, and help with mitigating system instability [28]. Various studies have stated that few profitable microgrid connections have enhanced energy access and further socio-economic results [30,34]. In addition, some research works have observed the combination of hybrid energy storage with stand-alone photovoltaic (PV) system to solve electrification problems in rural areas. Globally, rural electrification is best considered to be achievable through microgrids built on renewable energy (RE) sources. When such microgrids are based on variable RE sources, it is not feasible to deliver quality high power service to the consumer of interest. In such cases pertaining to Africa, it is reasonable to explore multi-scale time-based variability presented by the available local solar resource, and its implications [35]. The expansion of utility grid to remote rural communities is verified as uneconomical for implementation in South African remote communities, hence the stand-alone solar PV microgrid. The operations of stand-alone PV systems have substantial dependence on batteries for satisfactory power demands. However, the performance, maintenance cost, and operational life of batteries also depend on the charging/discharging phases, to which the frequent fluctuation in weather conditions aids [36]. As a stand-alone and self-sustaining system, the microgrid provides aggregate benefits to the community and increases supply redundancy factor with likely lower cost of over-sizing system modules. Meanwhile, the intermittent renewable generation results in some adverse effects that need to be minimized. The energy storage unit help to keep the excess produced power from the renewables, dispatch some during poor distributed energy resources conditions [37]. A detailed modeling and analysis is therefore necessary to standardize the DC voltage level and establish the overall efficiency of the selected microgrid system regardless of the loads $[38,39]$. The design requires unique criteria-based modeling with factors such as batteries sizing, battery type, daily load, discharge limit, number and autonomy of required days, system voltage, and operating conditions. However, beside meeting the battery type and storage capacity required, the final selection takes into consideration the comparative battery cycle performance to failure at the specified discharge depth. In addition, the resulting design must critically observe the cabling cost for any 10-km radius transmission and distribution across the villages [37].

\subsection{Microgrid Power Architecture}

In adopting the microgrid technology, the architectures and the control strategies used are very important. Grid strategy must have the capacity for convenience in both grid-connected and insulated mode to function. Hayden and Ceh [31] recognized several significant categories of microgrids including: campus or institutional microgrids, community microgrids, remote off-grid microgrids, military base microgrids, commercial and industrial microgrids. A microgrid can also be classified based on the structure of transmitting and distributing the microgrid power including DC, AC (high frequency and line frequency), and hybrid (DC-AC) microgrids. In addition, the microgrids can be identified based on the interfaces as either power electronically coupled or rotating generator based [40]. Other categorized microgrids include single or three-phase, low or medium voltage connected, and grid or islanded operation connected [40-42]. The distinct types have different operational requirements and control schemes. The different architectures and the control strategies of microgrids have been discussed in many studies [12,24-26,43-50]. Microgrids are more than capable of connecting and disconnecting from the utility grid, and if necessary they can independently function efficiently to support the local loads. A typical architecture of a microgrid is illustrated in Figure 3, showing the versatility in the concept as it accommodates micro-generators, local storage units, and the loads. 
The connected loads continuously influence the reliability of stand-alone microgrids. However, it is imperatively fundamental to strategically design suitable and flexible architecture of microgrid system which is proficiently operational in both grid-connected and isolated methods, and is presently essential [51-54]. Therefore, it is critical to explore and review different topologies, designs, architectures, and expansions of microgrid networks. More importantly, the application architecture and control strategies should indicate the significant contribution and integrated collaboration of basic microgrid components with the utility grid as we transition into a clean distributed energy future $[55,56]$.

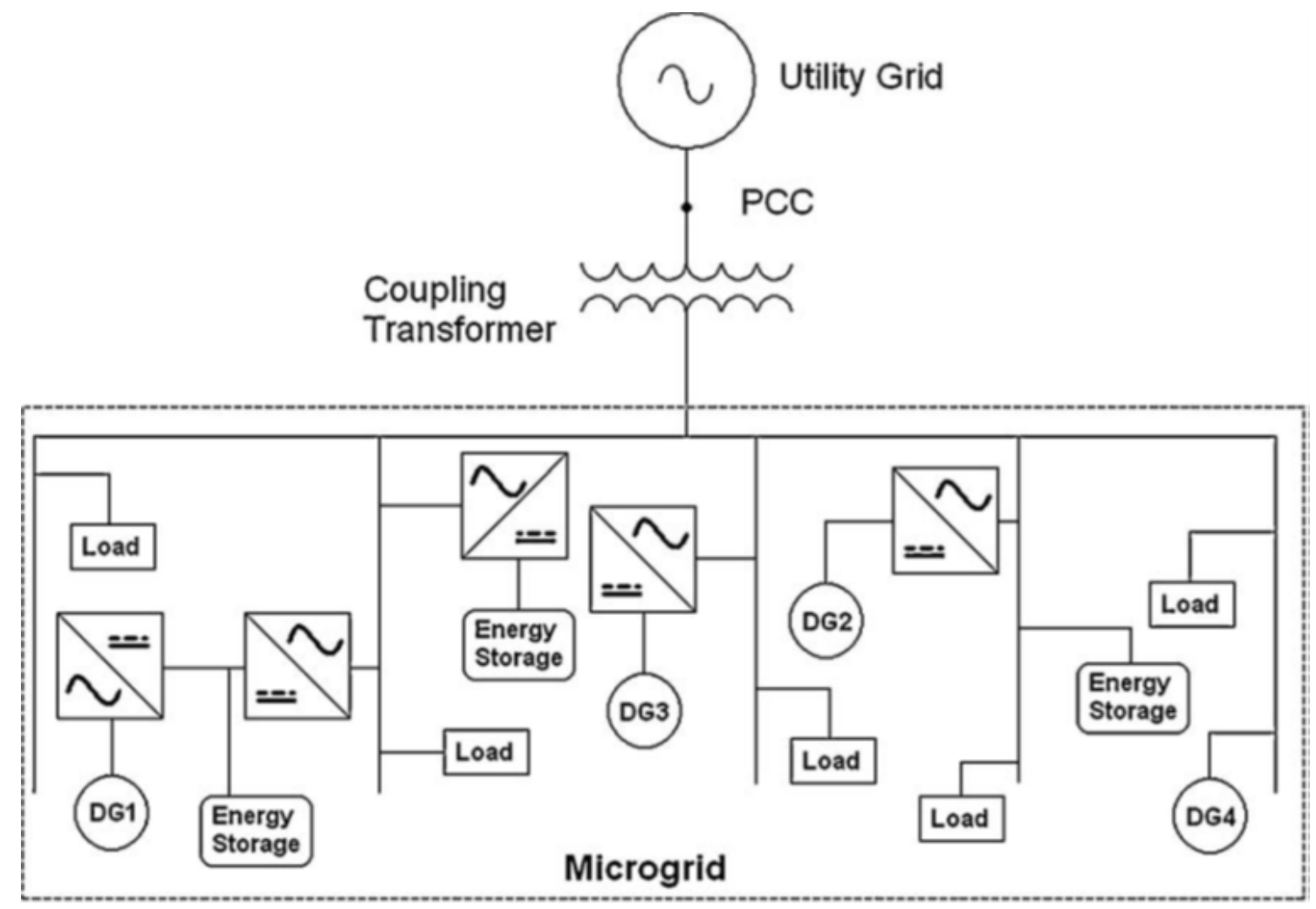

Figure 3. A typical architecture of a microgrid.

\subsubsection{Microgrid Architecture}

DC Microgrid is defined as an electrical servicing unit to efficiently transmit, consume, and ultimately supply and maintain DC power to a wide variety of electrical equipment across households when connected to an electrical grid or as an island [46,53]. Nowadays, in the renewable energy culture, DC Microgrid is assuming a new level, and attractively becoming a growing fashionable integrated solution for different kinds of industrial, residential, and DC powered household functions $[45,57,58]$. Hence, DC microgrids are an attractive choice for application to solving rural electrification in South African remote communities. The architecture of DC microgrids is relatively studied in this paper in comparison with the AC microgrid complement. The energy sources and electrical loads can be completely distributed in a more efficient and proficient DC network scheme, by electing an applied voltage level and therefore escaping a few makeover phases. However, energy storage devices could usually be directly interconnected primarily to DC bus via a high efficient DC/DC converter $[54,59,60]$. AC grids interface with DC microgrids through AC-DC converters with a step-down transformer being connected to a medium voltage $\mathrm{AC}$ network on the $\mathrm{AC}$ side. The application requirement of the microgrid determines the AC-DC converter topology to be adopted, whether bidirectional power flow (active front end) or unidirectional based topology [53]. During any power outages, DC microgrid battery storage uninterruptedly provides energy to the electrical loads in the AC main network. Most generators, which are distributed, consist of an electrical DC/DC converter or an AC/DC switch to 
connect to the bus. Occasionally, DC loads can be directly interrelated to the DC bus or a DC/DC converter may be required, probably depending on the bus voltage. However, DC microgrids have tremendous advantages over AC microgrids, which include the enhancement of effectiveness, stability, dependability, and lastly lack of reactive power. The DC microgrid architecture central limitation is the associated bidirectional AC/DC arrangement which manages complete energy flow from or to the utility network as it results in reliability reduction [54]. Subsequently, the most significant AC/DC converter maintains and controls the voltage of DC bus of which is of higher quality even when distribution grids are of low quality [61].

\subsubsection{AC Microgrid Architecture}

This AC microgrid architecture is operational in grid-connected approach, whereby energy is flowing directly from the utility grid. The supply avoids any kind of series related converter thereby ensuring prominent dependability or high reliability [52]. AC interfaces are utilized to connect any device to the microgrid framework and comprise one or more AC buses and many distributed generators using DC/AC power electrical interfaces. The architectural technique of transmission has been utilized to supply more effective and sustainable power conversion for efficiency, compared to the different architectures utilized in data centers [62,63]. The AC architecture is shown in Figure 4a in comparison to the DC microgrid illustrated in Figure $4 \mathrm{~b}$.

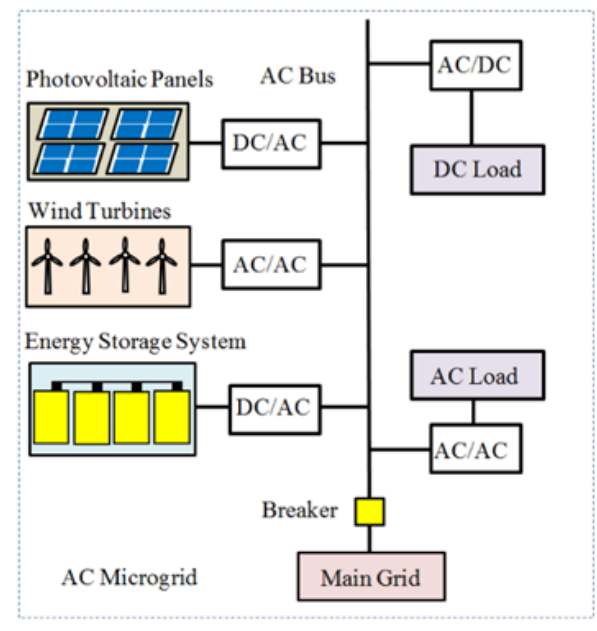

(a)

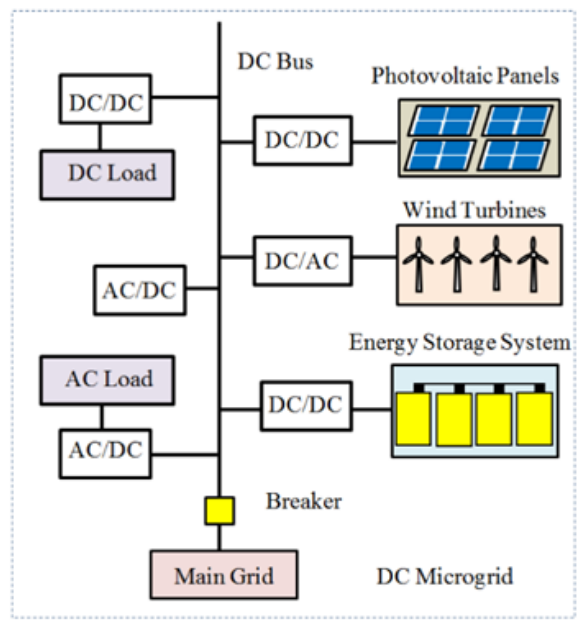

(b)

Figure 4. Architecture comparison: (a) AC microgrid; and (b) DC microgrid.

The AC power is converted to DC via the AC-DC converters to supply DC loads, while AC loads are connected directly through the AC bus. AC microgrid provides the possibility of voltage step-up for long-distance distribution. In the grid mode, abnormal conditions in grid result in the AC microgrid isolating itself and protecting the load within the microgrid network. Therefore, AC loads in the microgrid are protected from the main grid disturbances. The loads are capable of direct interconnection within the microgrid circuit without prior conversion. However, the conversion of AC to DC for DC loads supply reduces the efficiency in the architecture and increases the main grid's harmonics. In addition, the possibility of integrating renewable energy sources is hampered because both the sources and the PV output are DC, which requires conversion to AC with the use of an inverter [29].

\subsubsection{Hybrid DC/AC Architecture}

Hybrid AC/DC microgrids have developed into a much more noticeable conventional power distribution network. This system is stimulated for effective incorporation of small distributed generation units into an existing distribution network [40,64]. Hybrid AC/DC Microgrid is the 
application that incorporates both architectures and advantages of AC and DC microgrids $[11,59,65]$. Bidirectional AC/DC (interlinking) converters combine AC and DC microgrids from side to side. Distributed generators (DG) can directly be associated with the AC or DC feeders, whereby AC loads can connect directly to AC feeder and DC loads to DC feeder [66]. The hybrid microgrid uses the DC section to connect the distributed energy storage system through bi-directional converters, while the PV systems and other DC energy sources are connected to the DC-DC converters, and the small gas and wind turbines are connected via rectifiers. Power converters are used to execute the decoupled control of AC and DC microgrid parts [67-70]. The features of the DC, AC, and hybrid microgrid architectures are summarized in Table 1.

Table 1. Features of the microgrid architectures.

\begin{tabular}{lll}
\hline & Advantages & Disadvantages \\
\hline DC Microgrids & $\begin{array}{l}\text { High system efficiency, power reliability, safety, } \\
\text { control simplicity }\end{array}$ & $\begin{array}{l}\text { more converters required; high initial } \\
\text { cost; efficiency metrics issue, inverters } \\
\text { required for ac loads }\end{array}$ \\
\hline AC Microgrids & $\begin{array}{l}\text { No inverter required for ac loads; integration } \\
\text { through ac bus, good synchronization for both } \\
\text { grid-connected and isolated mode }\end{array}$ & $\begin{array}{l}\text { operation and control difficulties; } \\
\text { reliability issues }\end{array}$ \\
\hline Hybrid Microgrids & $\begin{array}{l}\text { Integration synchronization merit, voltage } \\
\text { transformation, economic feasibility }\end{array}$ & protection and control complexity \\
\hline
\end{tabular}

\subsection{Microgrid Control Architecture}

Microgrids are designed to adapt to the operational requirements of the operating modes: either grid-connected mode or islanded mode. Hence, the necessity for distinguishing control schemes. In grid-connected mode, micro-resources operationally inject power into the grid, the present model. Meanwhile, in the islanded mode, microgrids have to switch to a voltage control mode to ensure that local loads are fed with constant voltage. The control strategies for microgrids take into account these modes of operation when switching from grid-connected mode to islanded operation, and the different microgrid components in each of the modes [71]. The hierarchical control strategies of microgrids are considered in four levels. Converter output control level accounts for regulating energy flow and shaping current output. Power-sharing control level is responsible for the distribution of power among numerous equivalent converters and influenced by communication associations. The supervisory control level is the secondary control, which caters for controlling parameters internal to the microgrids and low-level controllers. In addition, the grid supervisory control level provides the tertiary control responsible for managing current flow between the utility grid and microgrid [71,72]. Based on communication mode, control strategies in DC microgrids could be categorized into decentralized, centralized, and distributed control, with their corresponding peculiar structures $[44,45,65]$. The reviewed control strategies for developing microgrid power quality, reliability, and power allocation methods are categorized as shown in Table 2.

The control strategies adopted for AC microgrids are more complex than those in their DC counterparts. In minimizing the circulating reactive current and mitigating the necessity for reactive power compensation, DC microgrids adopt P-V droop while AC microgrids employ reactive $(\mathrm{Q}-\mathrm{V})$ and real (P-f) droop. The simplified control strategies for DC microgrids contribute to their higher resilience [73-75]. DC microgrids use a set of control strategies for soft-start control, restoring of the DC system voltage deviation through an external controller, and current/power flow regulation in or out of the stiff DC source or a connected power converter to a possible AC grid [76-78]. Algorithms for the control strategies in DC microgrids need to be designed for transitioning from grid-connected to islanded mode. However, the power-sharing among the DG units in the islanded system vary between the decentralized and centralized control approaches [76,79-82]. Considering the droop-characteristics 
shown in Figure 5, the sharing of the active power within the DG units of a DC microgrid can be obtained using the following equation [62]:

$$
V_{d c i}=V_{d c}^{\prime}-\alpha_{v i} \cdot P_{i}
$$

where $\alpha_{v i}$ is the droop gradient coefficient; $V_{d c i}$ and $V_{d c}^{\prime}$ are, respectively, the measured DC voltage, and the reference voltage value; $P$ represents the active power difference between the active power set-point and the corresponding instantaneous shared value; and $i=1,2,3 \ldots n$ is the number count of the DG units. Meanwhile, the DG unit ratings and operating conditions, as well as minimal voltage variations must be considered when tuning the droop gradient coefficient [62,83-85].

Table 2. Categorization of the control strategies.

\begin{tabular}{ll}
\hline Basis & Control Strategies \\
\hline Communication mode & Decentralized, centralized and distributed approach \\
\hline Hierarchical control & Converter output, power-sharing, supervisory control, and tertiary control \\
\hline System-level control & Peer-to-peer control or master-slave control \\
\hline Device-level control & $\begin{array}{l}\text { Droop control, voltage/frequency control, p/q control, virtual flux } \\
\text { control, adaptive derivation }\end{array}$ \\
\hline Grid-connected operational mode & Micro-resources operationally inject power into the grid \\
\hline Islanding operational mode & $\begin{array}{l}\text { Microgrids switches to a voltage control mode to ensure that local loads } \\
\text { are fed with constant voltage }\end{array}$ \\
\hline
\end{tabular}

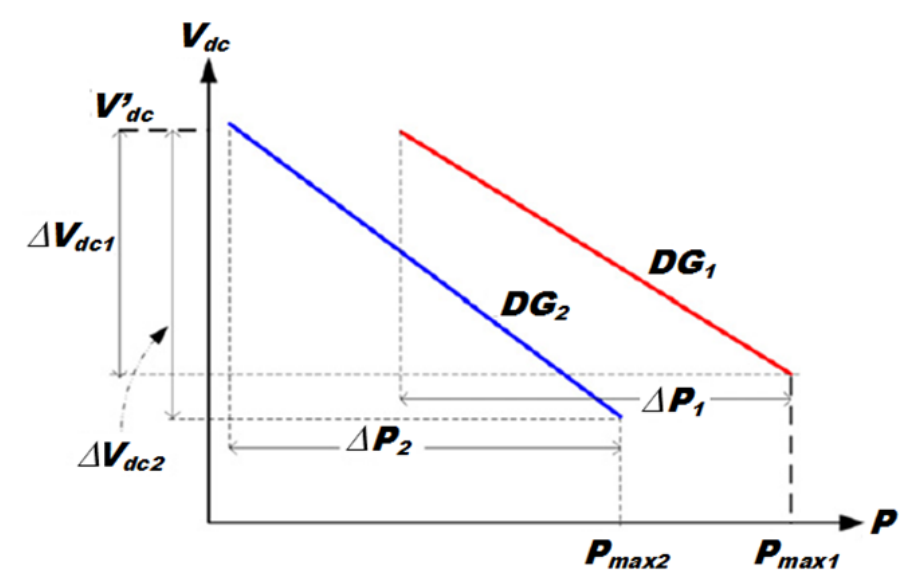

Figure 5. Control strategy for DC microgrid system using droop-characteristics.

In addition to the various alternative projects being executed by the SAG, it recently embarked on supporting the implementation of some microgrid projects with innovative solutions with relative success. An integrated solar diesel microgrid architecture was commissioned by ABB in 2016 at the long-meadow vicinity in Johannesburg. In addition, Robben Island solar PV microgrid and Singita Kruger National Park microgrid projects were implemented as predominantly combining solar $\mathrm{PV}$ and lithium-ion storage microgrid framework. To ensure seamless power supply, the launched projects combine distributed control systems (DCSs), intelligent power controllers, and integrated multiple controllers (IMCs) of solar PV, energy storage and generators. The microgrid controllers are considered as the microgrid brain for ensuring both on-site and off-site supply. Other projects include the Wilhelmina farm solar microgrid and Touwsrivier concentrated photovoltaics (CPV) solar power projects, and few others implemented and commissioned in the Northern Cape and Eastern Cape provinces of South Africa. In totalm, about 30 solar PV plants with power capacity of 5-75 
MW each were implemented by the SAG under the Renewable Energy Independent Power Producer Procurement Programme (REIPPPP), as illustrated in Table 3, and are situated in different locations within the country $[86,87]$.

Table 3. Some Solar Photovoltaic Facilities Approved by SAG in REIPPPP.

\begin{tabular}{lc}
\hline Project Details & Rated Output (MW) \\
\hline SlimSun Swartland Solar Park & 5.0 \\
Vredendal Solar Park & 8.8 \\
Upington Solar PV & 8.9 \\
Aurora Solar Park & 9.0 \\
Mulilo Renewable Energy Solar PV De Aar & 9.7 \\
Greefspan PV Power Plant & 10.0 \\
Mulilo Renewable Energy Solar PV Prieska & 19.9 \\
Soutpan Solar Park & 28.0 \\
Touwsrivier Project (CPV) & 36.3 \\
SA Mainstream Renewable Power Droogfontein & 48.3 \\
Boshoff Solar Park & 60.0 \\
Lesedi Power Company & 64.0 \\
Dreunberg Solar PV & 69.6 \\
Sishen Solar Facility & 74.0 \\
Jasper Power Company & 75.0 \\
\hline
\end{tabular}

Meanwhile, the analysis and comparison of the feasible sustainability of the microgrid types are based on varying economic parameters. The rural electrification strategies can be compared based on performance, efficiency, cost, equipment utilization, power quality, excess of energy produced, and the environmental impacts. Using cost factor as parameter of interest, the cost of constituent components such as Solar PV array, converters, inverters, and battery storage systems should be accurately estimated for correct determination of the system energy efficiency. This forms the basis for harmonizing cost optimization method and the robust design of the systems. DC or AC microgrid has its particular efficiency reliant on the quantity of conversion phases within the system. The perception of sustainability is about the utilization of energy resources in an approach considered to be adequate. Other long-term projects were also targeted for sub-urban centers with relatively greater capacities and costs. Some of these projects are shown in Table 4 [88-91].

Table 4. Some of SA renewable energy projects with capacities and estimated costs in South African Rands (ZAR).

\begin{tabular}{ccc}
\hline Project Names & Capacities (MW) & Estimated Cost (ZAR) \\
\hline Khathu Solar Park & 100 & 12 billion \\
Jasper Solar Power & 96 & 2.3 billion \\
Solar Capital De Aar Project 1 and 2 & 175 & 7.2 billion \\
Mulilo Prieska PV & 86 & 1.3 billion \\
Kalkbult solar power & 75 & - \\
Robben Island solar PV microgrid & 1 & 25 million \\
\hline
\end{tabular}

The SAG previously pursued sustainable policies to legally regulate the possible implementation of cumulative RE-based power projects with capacity greater than $5 \mathrm{MW}$. It contributed a tax incentive through the South African Revenue Service for the installation and commission of photovoltaic solar energy production systems. The target of the policy was remote rural communities with no access to the utility grid. Most of the configurations were hybrid microgrid architectures made up of solar PV, diesel, and wind. This system infrastructures were considered as innovative solutions to resolve the country energy crisis at a larger landscape but the sources require a review and improvement. The government eventually realized the necessity of allowing public-private partnership in the process 
of guaranteeing energy security. A policy has thus been promulgated to accommodate the various interests at achieving success over the energy limitations. The policy model has two parts: mid-term plan for the REIPPPP and the long-term standard containing the Integrated Resource Plan (IRP 2010) of 2010 to 2030 [86].

\section{Policy Framework for Microgrid Systems in South Africa}

The right regulation and policy framework for microgrid implementation in South African remote areas is vital and required. Microgrids encounter global regulation challenges concerning policies, protection issues, consumers and power suppliers engagements, legalities, operation limitations, renewable sources integration, and microgrid interconnection with utility grid containing higher connectivity costs as a result of high policies association fee. Hence, amongst microgrids and utility grids are interconnection guidelines which are formulated for the regulation purpose of the development and management of DG integration impacts without disturbance of the utility grid safety and functionality [85]. Access to electricity for rural remote areas is one of the most important issues in Africa, with success depending on governments, investors, and energy policymakers [90]. South Africa has the biggest developing economy with great potential for microgrid systems. The potential of microgrids and its investments is threatened by skewed and limited policies in the country. The SAG as well as some other African countries are supporting and promoting the attention of microgrid investment by developing healthy policies and incentive structure [63]. The existing policy frameworks in SA are fully designed for grid electrification, which is skew and against the possibility of microgrid application. The energy sectors in South Africa, as in some other African economies, are primarily managed by competitive policies, rules, regulations, and monopolistic laws which unfortunately support grid electrification and ultimately limit rural electrification. Countries are beginning to review these policies and laws so that they could in-house private sector participation and other energy key players [19,91-93]. The limited policy framework of microgrid systems could reduce their desirable potential and success since governing support and distribution opportunities will be inadequate. The SAG is the fundamental player in formulating microgrid policy framework and providing funding for microgrid projects taking place in the country. Microgrid advocates and policymakers need to formulate and execute policies which could mitigate any associated issues to microgrids and produce a continuously perfect microgrid environment [30]. Various studies have highlighted the microgrid technologies with shortage on policies, barriers, and incentives on microgrid deployment and promotion. Microgrid policies should be related to policies on distributed and renewable energy. The policy framework of the system should indicate an essential need to evaluate the functionality of microgrid policies and regulations which are considered issues influencing adoption of the microgrid as an innovative distribution framework [49]. The issues, barriers, and challenges of the regulations and policies are knotted as highlighted in Figure 6.

Sustainable microgrid operation in remotely situated rural areas can quickly progress forward if the policies and regulations of microgrid systems are successfully formulated and addressed. However, to support distribution and operation in microgrid systems, there is a necessity to articulate regulations and policies which encourages the integration of renewable energy sources (RES) and DG into the traditional grid, to subsequently increase energy source security and competitive cost-effective advantage [68]. RE and innovative networks are presenting a new opportunity for a meaningful contribution to global energy access. The new emerging innovation is the combination of RE and minior microgrids for grid-quality power to remote communities [94]. 


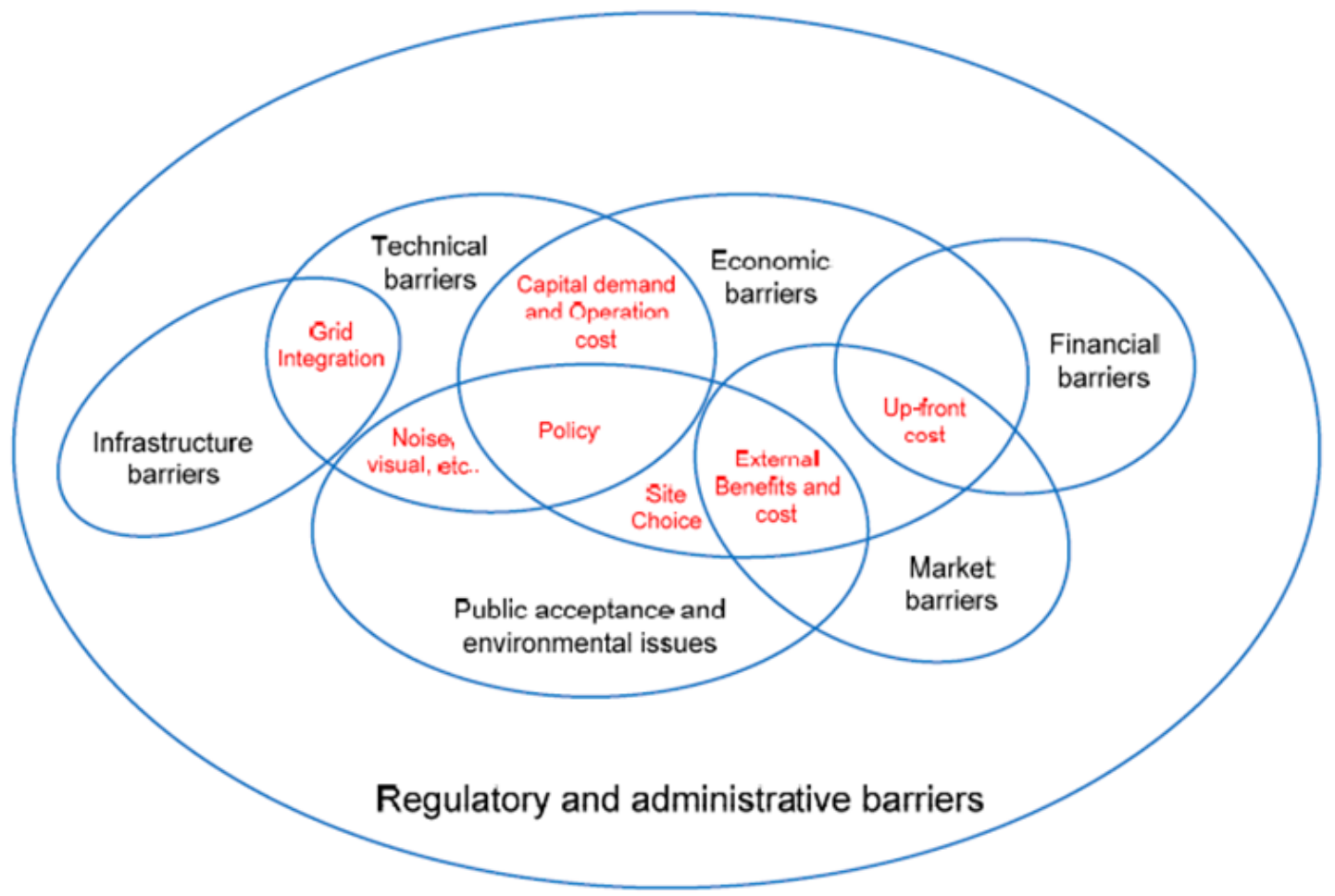

Figure 6. Development barriers for microgrid renewable energy [50].

\subsection{Existing Energy Policy Charter}

The SAG stands good stead to produce an effective policy framework which would enable successful implementation and operation of RE-microgrids systems $[64,95,96]$. South Africa is affiliated with International Renewable Energy Agency (IRENA), an international institution which supports and upholds the utilization of renewable energy policies, with major objectives in policy-making aids and sustainable energy technology supply to its member countries $[97,98]$. Presently, the three energy policy frameworks hitherto developed by SAG as illustrated in Figure 7, are the White Paper on Energy Policy in 1998, the White Paper on Renewable Energy Policy in 2003, and the National Climate Change Response Policy White Paper in 2011. The specific objectives of the policy documents are summarized to include improved access to low-cost energy services, enabling effective energy governance, securing energy source diversity, ensuring and managing the consequences of environmental impacts, encouraging cost-effective growth $[11,95,96,99,100]$.

The Integrated Energy Plan (IEP) and Integrated Resources Plan (IRP) are the other strategic policy documents by the SAG as interventions for shaping and outlining essential future of renewable energy sources in South Africa $[90,95,100]$. These charters focused on the secondary level of energy application and operations. The IEP was a gazette in 2016 to provide an imperative framework for South Africa's sustainable energy environment and support future investment in the energy infrastructure and policies improvement [95]. The SAG failed to approve IRP 2010 and subsequently in a policy framework limbo because IRP 2013, IRP 2016, and IRP 2018 were never approved. The last of the pack is the IRP 2019, which is not yet approved. Consequently, there is a negative outlook for the SA renewable energy policy, resulting in substantial holdback of investment in the sector to guarantee system flexibility and efficiency [61-63]. An effective IRP implementation is necessary for accomplishing the overall energy sector transformation to meet the demand across SA cities and rural communities in the next 20 to 40 years $[61,97,98]$. 


\subsection{Policy Options for RE-Microgrid Implementations}

The prime recurring factors of consideration in formulating policy for investing in RE-microgrid systems include the required cost, lack of existing supporting systems for implementation, and the non-financial effects on social and psychological factors. The decision-making process requires a multi-lateral appraisal of the factors for selection, as discussed in the subsection here. The significance attached to each category of factors for evaluating RE systems varies from one study to the other. In few cases, relevance are given to the economic, technical, social, and environmental categories with which the importance of deriving conclusions from quantifying valuation criteria are highlighted to support the categories. However, studies that attach relative importance to assessing socio-political effect in evaluating RE systems are deemed non-suitable for South Africa scenario [92]. The SAG should explore various policy options in promoting the integration of RE with microgrids systems to support effective and sustainable power provision for remote rural communities. The experience with some industrialized nations and economies will guide the choice of policy options, and make available insights into implementing them. The component integration and improvement on the existing policy papers would enable a speedy and robust framework, as depicted in Figure 7, to adequately address the need for affordable and quality energy access in the dispersed rural areas.

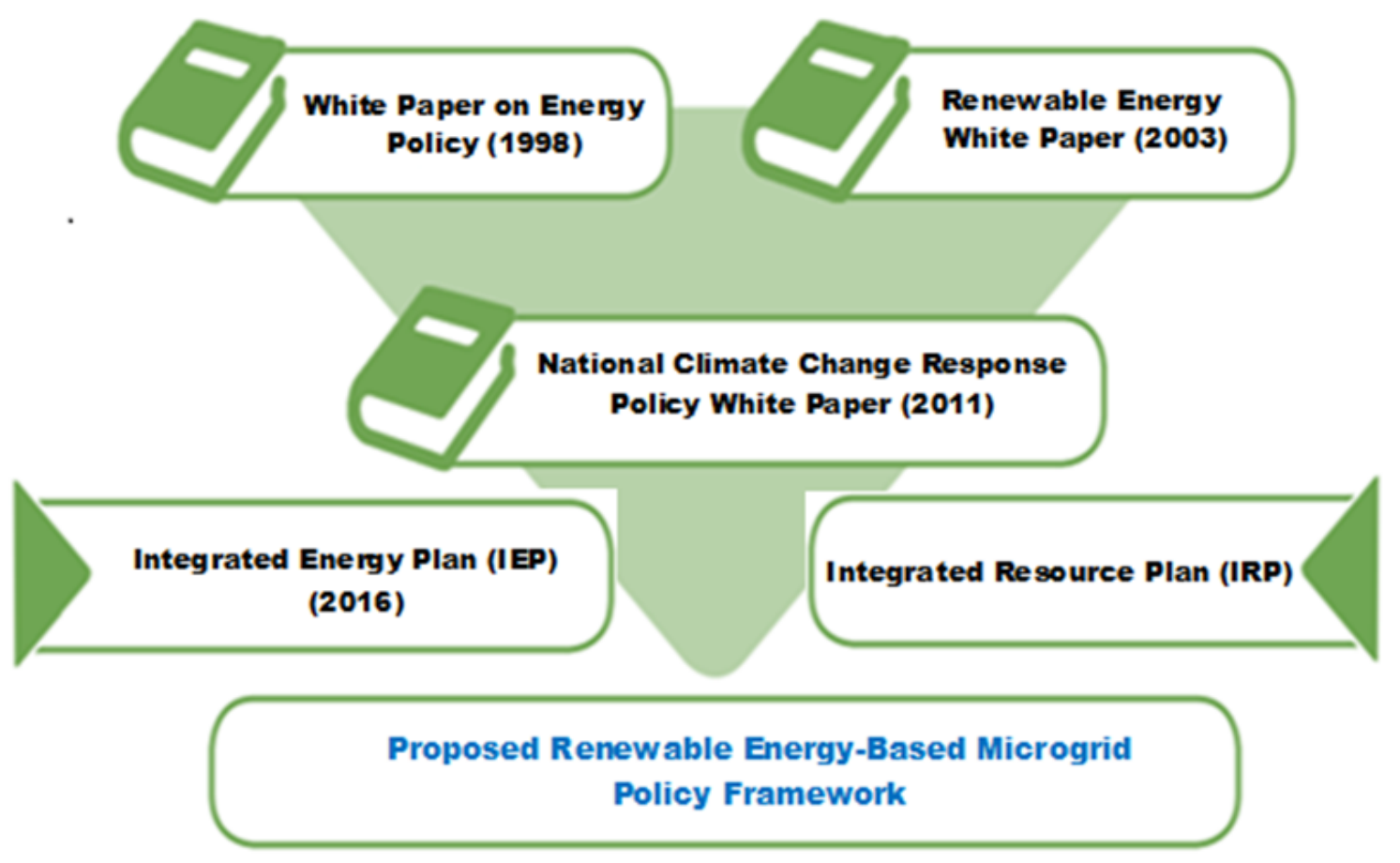

Figure 7. Energy policy framework in South Africa.

\subsubsection{Private-Sector Partnership}

Across the world, there is significant focus on policy mechanisms that encourage increasing renewable energy supplies. The nexus and most agreeable model in RE-microgrid policy making is by ensuring less funding by the government on new investment, benefits for private partners from installing and handling new technologies, and public benefitting through social, economic, and environmental sustainability. The model allows government to directly regulate the cost incurred by the consumers or indirectly through empowered regulators. Basically, the policy framework incorporates four major classes: feed laws that obligate fixed-rate tariffs within the energy networks; quotas that define the proportion or renewable portfolio standard indebted to the electricity suppliers; financial incentives that cater for the grants and/or exempted taxes; and competitive tendering on behalf of government contracts for energy generation which oblige the suppliers to buy the RE at a first-rate 
price to be recovered from consumers' levies [87,99]. A viable policy framework for RE-microgrid systems to ensure rural electrification in South Africa will require the SAG to introduce different measures to promote private-partnership investment in the energy sector. The investment cycle in the sector is comparatively long. Therefore, the private sector partnership should be ensured as soon as possible. The government recognized this importance in the advent of renewable energy and other clean technologies and took steps to support them while imitating successful case studies in other economies. The supporting measures for adoption include feed-in tariffs [101], quota models, tax incentives or subsidies for the enabling technologies such as photovoltaic (PVC) and clean energy technologies, and a cap-and-trade system [102]. Currently, SA has emulated China and India in introducing tax exemption for clean development mechanism (CDM), intending to attract substantial investments to the projects. The global overview of the distribution of the CDM projects is shown in Table 5.

Table 5. Distribution of global clean development mechanism projects.

\begin{tabular}{cc}
\hline Country & \% CDM Projects \\
\hline China & 36 \\
India & 26 \\
Brasil & 7 \\
Mexico & 4 \\
South Africa & 1 \\
Others & 26 \\
\hline
\end{tabular}

South Africa is providing a favorable atmosphere for CDM project investment and development. The SAG can employ the various incentives in the enhanced policy actionable plan to reflect cater to climate change issues, energy security, and profitable returns on private investments. As electricity access remains a human right issue in SA and the economic activities in the target areas for electrification are low, the government is faced with fashioning a policy plan that will clearly outline the short- or long-term basis of private investment returns. The relativity of pricing to capacity for returns in investment such as explained in detail in Section 3.2, is illustrated in Figure 8. The current capacity of the energy is represented by Q1, while the next installed new plant capacity is represented by Q2. Relative to the capital investment at Q1, demand is much lower than the available supply. As the demand increases with the addition of new users, a point of equality will be reached between the two.

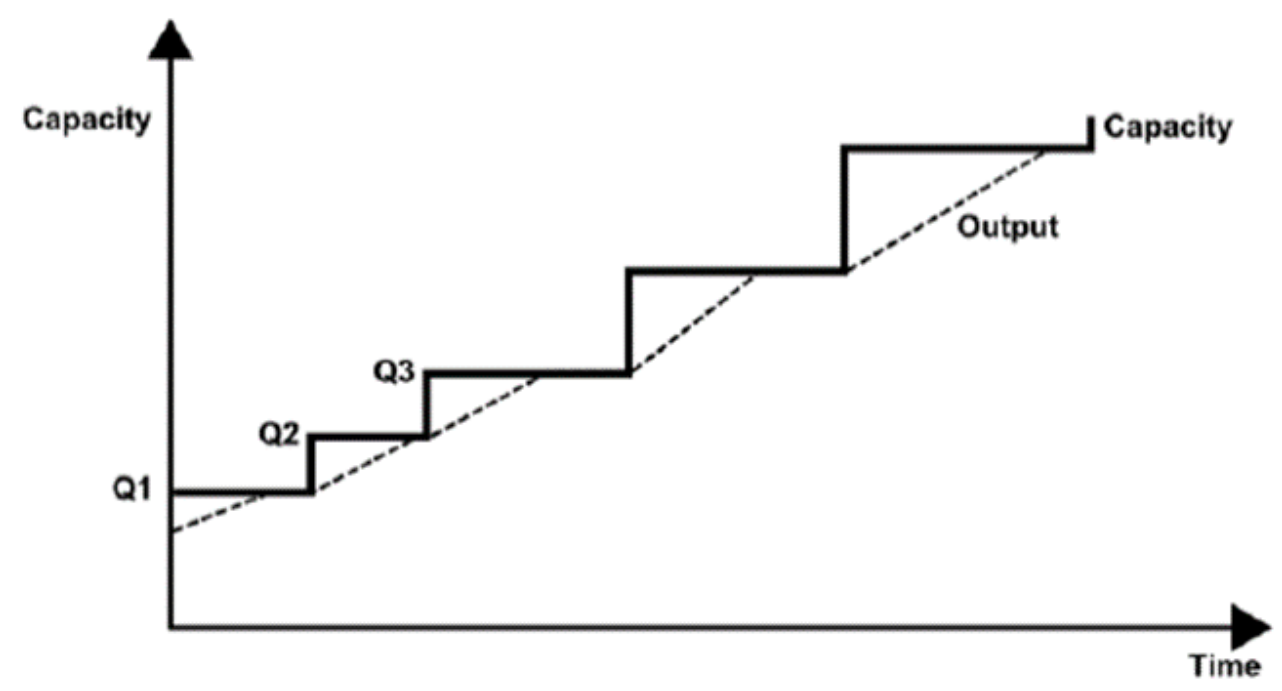

Figure 8. Indication of lumpy investment on SMC-based pricing. 


\subsubsection{Power Generation Target}

The SAG can set the target of the power generation level expected from the RE-based microgrid platform, by parameterizing a substantial amount of energy demand of the target areas to be acquired from it. This will form a key mechanism for evaluating the value addition of the platform without depending on the market assessment of the social and environmental benefits. Government has always involved such targets in its previous policy efforts. In the RE paper of 2003, a target of annual additional 10,000 GWh to the final energy capacity was set to be achieved by 2013 [103]. In addition, the SA power utility company Eskom has targeted the power generating capacity of the country at 4000 MW from renewable sources by this year, about $8.3 \%$ of the total output. This supports a projection of about $15 \%$ renewable generation by a research study at the University of Cape Town. The SAG should be committed to the development of RE-microgrid strategy to translate the set-out objectives, goals, and deliverables into a policy and implementation plan [11,65,101,102].

\subsubsection{Electricity Pricing}

Another policy instrument to achieve the desired framework in the implementation of RE-microgrid systems is price-fixing through tariff regulation. A major feature of the existing energy regime in South Africa is the low-cost of electricity sales, one of the lowest globally. The two enabling factors for the low price are the use of the largely available low-grade coal and the pricing policy in practice. Designing a policy framework, an efficient and cost-reflective tariff which also satisfies a range of economic, social, and political objectives can be incorporated. The policy needs to guarantee that set-targets of electrification are met, and ensure low-cost electricity provision, improved quality and security of power supply, enhanced price equality, proper operation and coordination of investments, protection of the existing competent workforce, and financial viability $[64,104,105]$. In arriving at the best pricing policy, both short-run marginal cost (SMC) and long-run marginal cost (LMC) approaches should be considered. While SRC is often an efficient pricing technique for goods and services, LMC is consistent with efficient economic resources allocation and relatively stable tariff path. The SMC can deal with incremental cost on an additional power unit provided generation capacity remains fixed, while LMC will cover such costs when all inputs vary. Therefore, the generation capacity installed over a period and variation of the different parameters will influence pricing method adopted. Importantly, the pricing policy needs to anticipate the incremental cost of supplying additional power unit with a continuous maintaining an optimal level capacity to supply projected demand for many years to come. In addition, it will ensure price stability, fair cost allocation based on burdens obligatory on the system, provision of minimum basic service to those unable to afford the cost, ensuring financial sustainability of the utility and administratively efficient tariff structure [106-109]. According to documents by National Energy Regulator of South Africa (NERSA) [110-112], a multi-year price determination (MYPD) methodology was employed by Eskom to determine its allowable revenue, as illustrated by Equations (3) and (4):

$$
\begin{gathered}
A_{r}=\left(R_{A B} W_{A C C}\right)+P_{C}+T \pm R_{C A} \\
P_{C}=E+P_{E}+D+T_{N C}+R_{C}+I_{D M}+S_{Q I}
\end{gathered}
$$

where $A_{r}$ is the allowable revenue, $R_{A B}$ is the regulatory asset base, $W_{A C C}$ is the weighted average cost of capital, $P_{C}$ is the pass through cost, $T$ is the government levies and taxes, $R_{C A}$ is the regulatory clearing account, $E$ is the expenses (operating and maintenance), $P_{E}$ is the primary energy, $D$ is depreciation, $T_{N C}$ is the transmission and network cost, $R_{C}$ is the research and development costs, $I_{D M}$ is the integrated demand management, and $S_{Q I}$ is the service quality incentive. 


\section{Conclusions}

Access to electricity is an important benefit to be guaranteed by the South Africa Government for all citizens and dwellers in the country. However, different rural communities still lack electricity, despite being a right supported by the country's laws. The feasible, affordable and sustainable approach to connecting the rural communities to electricity supply is suggestively through the use of microgrid solutions. Microgrids are undoubtedly beginning to fundamentally undertake a strategic function in the expansion of smart-grids. There are several discrepancies in the implementation of microgrid architectures and designs. Whereas most literature focuses predominantly on the AC and DC microgrids, hybrid AC/DC networks are phenomenal alternatives, which are imperatively combining the benefits of the two aforementioned configurations. Energy storage devices in the application of microgrid are fundamental segments, which make microgrid systems to be proficient, stable, and efficient in their operations. The review of the various architectures of microgrids shows that AC microgrids could be observed as one of the most stable and reliable microgrids because their current AC installations can be simply redesigned for architectural implementation with only minimal adjustment of their components, allowing the current AC loads to be reused. Meanwhile, DC microgrid configurations are proposed to be suitable solutions for providing reliable electricity access to rural remote communities due to their higher efficiency, reliability, stability, load-sharing performance, and ability to be connected to DC renewable and storage sources. These beneficial advantages of the proposed system make it outstanding and gain a competitive advantage over other microgrids systems. The system presents benefits such as a reduction of operating and maintenance cost. DC microgrids can entirely function while disconnected from the utility grid, which is called an isolated operation approach. DC microgrids are a cost-effective option with a capacity to supply electricity for areas in developing countries. Both AC and DC microgrid configuration require to be modernized and modified in order to meet the respective target customer demands. DC microgrid is currently in the expansion phase due to the improvement of sustainable renewable energy sources and energy storage systems. The expansion of DC microgrid encounters an imperative limitation in the current power framework, i.e. the smaller quantity of DC loads. DC microgrids, as with other types, require a set of hierarchical control strategies for their operation and applications. DC microgrids use the control strategies for soft-start control, restoring of the DC system voltage deviation through an external controller, and current/power flow regulation in or out of the stiff DC source or a connected power converter to a possible AC grid. Algorithms for the control strategies in DC microgrids are designed requirement for transitioning from grid-connected to islanded mode. However, the power-sharing among the DG units in the islanded system vary between the decentralized and centralized control approaches. It is extremely significant for policymakers and governments to formulate and implement policies that stimulate efficient, dependable, and competitive policy framework for microgrids. Policies are considering changing to in-house dissimilar forms of microgrid systems and designed to diversify combination of distributed and renewable energy resources. A well-structured policy framework of governments is the dynamic driving force towards successful implementation of renewable energy systems. In addition, sustainable microgrid operation in remotely situated rural areas can quickly progress if the policies and regulations of microgrid systems are successfully formulated and addressed. However, the gap among microgrid architecture, renewable energy policy framework, and the actual application is relatively extensive. The component integration and improvement on the existing policy papers would enable a speedy and robust framework that can guarantee private-sector partnership on investment, meeting power generation target and ensuring the right electricity pricing to ensure attractive returns on investment both in the short-term and long-term basis.

Author Contributions: Conceptualization, P.N.B. and V.M.; methodology, V.M. and M.O.O.; validation, V.M., P.N.B. and M.O.O.; formal analysis, V.M. and M.O.O.; investigation, V.M. and M.O.O.; resources, V.M.; data curation,V.M.; writing-original draft preparation, V.M.; writing-review and editing, M.O.O. and P.N.B.; supervision, P.N.B. and M.O.O.; project administration, V.M.; funding acquisition, P.N.B. All authors have read and agreed to the published version of the manuscript. 
Funding: This research received no external funding and the APC was funded by the Faculty of Engineering and the Built Environment (FEBE) of the University of Johannesburg.

Conflicts of Interest: The authors declare no conflict of interest.

\section{References}

1. Densmore, A.; Prasad, G. An energy market for rural, islanded micro-grids. In Proceedings of the International Conference on the Domestic Use of Energy (DUE), Cape Town, South Africa, 31 March-1 April 2015; pp. 123-130.

2. Ahlborg, H.; Hammar, L. Drivers and barriers to rural electrification in tanzania and Mozambique-Gridextension, off-grid, and renewable energy technologies. Renew. Energy 2014, 61, 117-124 [CrossRef]

3. Garfunkel, S. From The Bottom Up. In A Fresh Start for Collegiate Mathematics: Rethinking the Courses below Calculus; Hastings, N., Ed.; Mathematical Association of America: Washington, DC, USA, 2006; pp. 345-347.

4. Dragicevic, T.; Lu, X.; Vasquez, J.C.; Guerrero, J.M. DC microgrids Part I: A review of control strategies and stabilization techniques. IEEE Trans. Power Electron. 2015, 31, 4876-4891. [CrossRef]

5. Akinbulire, T.O.; Oluseyi, P.O.; Babatunde, O.M. Techno-economic and environmental evaluation of demand side management techniques for rural electrification in Ibadan, Nigeria. Int. J. Energy Environ. Eng. 2014, 5, 375-385. [CrossRef]

6. Bhattacharyya, S.C.; Palit, D. Mini-grids for rural electrification of developing countries: Analysis and case studies from South Asia. Energy Policy 2016, 94, 166-178. [CrossRef]

7. Wells, V.; Greenwell, F.; Covey, J.; Rosenthal, H.E.S.; Adcock, M.; Gregory-Smith, D. An exploratory investigation of barriers and enablers affecting investment in renewable companies and technologies in the UK. Interface Focus 2013, 3, 20120039. [CrossRef]

8. Ighravwe, D.; Babatunde, M. Selection of a mini-grid business model for developing countries using CRITIC-TOPSIS with interval type-2 fuzzy sets. Decis. Sci. Lett. 2018, 7, 427-442. [CrossRef]

9. Anderson, T.; Doig, A.; Rees, D.; Khennas, S. Rural Energy Services: A Handbook for Sustainable Energy Development; Intermediate Technology Publications Ltd. (ITP): London, UK, 1999.

10. Mini-Grid Policy Tool-kit. Policy and Business Frameworks for Successful Mini-Grid Roll-Outs. Available online: http:/ / www.euei-pdf.org/en/recp/mini-grid-policy-toolkit (accessed on 18 March 2020).

11. Winkler, H.; Hughes, A.; Haw, M. Technology learning for renewable energy: Implications for South Africa's long-term mitigation scenarios. Energy Policy 2009, 37, 4987-4996. [CrossRef]

12. Lidula, N.W.A.; Rajapakse, A.D. Microgrids research: A review of experimental microgrids and test systems. Renew. Sustain. Energy Rev. 2011, 15, 186-202. [CrossRef]

13. Krause, M.; Nordström, S. Solar Photovoltaics in Africa: Experiences with Financing and Delivery Models, Lessons for the Future; Monitoring and Evaluation Report Series, Issue 2; United Nations Development Programme (UNDP) and Global Environment Facility: New York, NY, USA, 2005.

14. Couture, T.; Gagnon, Y. An analysis of feed-in tariff remuneration models: Implications for renewable energy investment. Energy Policy 2010, 38, 955-965. [CrossRef]

15. Martinot, E.; Chaurey, A.; Lew, D.; Moreira, J.R.; Wamukonya, N. Renewable energy markets in developing countries. Annu. Rev. Energy Environ. 2002, 27, 309-348. [CrossRef]

16. Tenenbaum, B.; Greacen, C.; Siyambalapitiya, T.; Knuckles, J. From the Bottom up: How Small Power Producers and Mini-Grids Can Deliver Electrification and Renewable Energy in Africa; The World Bank Publications: Washington, DC, USA, 2014.

17. Ratshomo, K.; Nembahe, R. South African Energy Sector Report. 2018. Available online: http:/ /www.energy. gov.za/files/media/explained/2018-South-African-Energy-Sector-Report (accessed on 18 March 2020).

18. South African Department of Energy. State of Renewable Energy in South Africa. 2015. Available online: http:/ / www.energy.gov.za/files/media/Pub/State-of-Renewable-Energy-in-South-Africa (accessed on 18 March 2020).

19. Pegels, A. Renewable energy in South Africa: Potentials, barriers and options for support. Energy Policy 2010, 38, 4945-4954. [CrossRef]

20. Guerrero, J.M.; Chandorkar, M.; Lee, T.L.; Loh, P.C. Advanced control architectures for intelligent microgrids, Part I: Decentralized and hierarchical control. IEEE Trans. Ind. Electron. 2012, 60, 1254-1262. [CrossRef] 
21. South African Department of Minerals and Energy. Government Gazette: Electricity Pricing Policy of the South African Electricity Supply Industry. 2008. Available online: https:/ / www.gov.za/documents/southafrican-electricity-supply-industry-electricity-pricing-policy-epp (accessed on 18 March 2020).

22. Platchkov, L.M.; Pollitt, M.G. The Economics of Energy (and Electricity) Demand; Electricity Policy Research Group: Cambridge, UK, 2011. Available online: www.eprg.group.cam.ac.uk (accessed on 18 March 2020).

23. Goosen, P.; Mathews, M.J.; Vosloo, J.C. Automated Electricity Bill Analysis in South Africa. S. Afr. J. Ind. Eng. 2017, 8, 66-77. [CrossRef]

24. Unamuno, E.; Barrena, J.A. Hybrid AC/DC microgrids Part 1: Review and classification of topologies. Renew. Sustain. Energy Rev. 2015, 52, 1251-1259. [CrossRef]

25. Unamuno, E.; Barrena, J.A. Hybrid AC/DC microgrids Part 2: Review and classification of control strategies. Renew. Sustain. Energy Rev. 2015, 52, 1123-1134. [CrossRef]

26. Hirsch, A.; Parag, Y.; Guerrero, J. Microgrids: A review of technologies, key drivers, and outstanding issues. Renew. Sustain. Energy Rev. 2018, 90, 402-411. [CrossRef]

27. Danish, M.S.S.; Senjyu, T.; Funabashia, T.; Ahmadi, M.; Ibrahimi, A.M.; Ohta, R.; Howlader, H.O.R.; Zaheb, H.; Sabory, N.R.; Sediqi, M.M. A sustainable microgrid: A sustainability and management-oriented approach. Energy Procedia 2019, 159, 160-167. [CrossRef]

28. Saleh, M.; Esa, Y.; Mohamed, A.A. Communication-based control for DC microgrids. IEEE Trans. Smart Grid 2018, 10, 2180-2195. [CrossRef]

29. Jadav, K.A.; Karkar, H.M.; Trivedi, I.N. A Review of microgrid architectures and control strategy. J. Inst. Eng. Ser. B 2017, 98, 591-598. [CrossRef]

30. Fowlie, M.; Khaitan, Y.; Wolfram, C.; Wolfson, D. Solar microgrids and remote energy access: How weak incentives can undermine smart technology. Econ. Energy Environ. Policy 2019, 8, 59-84. [CrossRef]

31. Hayden, E.; Ceh, C. Introduction to Microgrids. Securicon Report. 2013. Available online: https:// www.scribd.com/document/377094860/Introduction-to-Microgrids-Securicon-2013-1-pdf (accessed on 18 March 2020).

32. Saleh, M.; Esa, Y.; Mhandi, Y.; Brandauer, W.; Mohamed, A. Design and implementation of CCNY DC microgrid testbed. In Proceedings of the 2016 IEEE Industry Applications Society Annual Meeting, Portland, OR, USA, 2-6 October 2016; pp. 1-7.

33. Bhoyar, R.; Bharatkar, S. Potential of Microsources, Renewable energy sources and application of Microgrids in Rural areas of Maharashtra state India. Energy Procedia 2012, 14, 2012-2018.

34. Borza, P.N.; Machedon-Pisu, M.; Hamza-Lup, F. Design of Wireless Sensors for IoT with Energy Storage and Communication Channel Heterogeneity. Sensors 2019, 19, 3364.

35. Plain, N.; Hingray, B.; Mathy, S. Accounting for low solar resource days to size $100 \%$ solar microgrids power systems in Africa. Renew. Energy 2019, 131, 448-458. [CrossRef]

36. Javed, K.; Ashfaq, H.; Singh, R.; Hussain, S.M.; Ustun, T.S. Design and performance analysis of a stand-alone PV system with hybrid energy storage for rural India. Electronics 2019, 8, 952.

37. Xu, Z.; Nthontho, M.; Chowdhury, S. Rural electrification implementation strategies through microgrid approach in South African context. Int. J. Electr. Power Energy Syst. 2016, 82, 452-465. [CrossRef]

38. Guerrero, J.M.; Vasquez, J.C.; Matas, J.; De Vicuña, L.G.; Castilla, M. Hierarchical control of droop-controlled $\mathrm{AC}$ and DC microgrids: A general approach towards standardization. IEEE Trans. Ind. Electron. 2010, 58, 158-172. [CrossRef]

39. Wang, D.; Locment, F.; Sechilariu, M. Modelling, Simulation, and Management Strategy of an Electric Vehicle Charging Station Based on a DC Microgrid. Appl. Sci. 2020, 10, 2053.

40. Wang, X.; Guerrero, J.M.; Blaabjerg, F.; Chen, Z. A Review of Power Electronics Based Microgrids. Int. J. Power Electron. 2012, 12, 181-192. [CrossRef]

41. Peng, F.Z.; Li, Y.W.; Tolbert, L.M. Control and protection of power electronics interfaced distributed generation systems in a customer-driven microgrid. In Proceedings of the 2009 IEEE Power \& Energy Society General Meeting, Calgary, AB, Canada, 26-30 July 2009; pp. 1-8.

42. Xialing, X.; Xiaoming, Z. Overview of the researches on distributed generation and microgrid. In Proceedings of the 2007 International Power Engineering Conference (IPEC 2007), Singapore, 3-6 December 2007; pp. 966-971.

43. Sudipta, C. Distributed intelligent energy management system for a singlephase high-frequency AC microgrid. IEEE Trans. Ind. Electron. 2007, 54, 97-109. 
44. Palizban, O. Kauhaniemi, K.; Guerrero, J.M. Microgrids in active network management—Part II: System operation, power quality and protection. Renew. Sustain. Energy Rev. 2014, 36, 440-451.

45. Dragicevic, T.; Lu, X.; Vasquez, J.; Guerrero, J. DC microgrids-Part II: A review of power architectures, applications, and standardization issues. IEEE Trans. Power Electron. 2015, 31, 3528-3549.

46. Patrao, I.; Figueres, E.; Garcerá, G.; González-Medina, R. Microgrid architectures for low voltage distributed generation. Renew. Sustain. Energy Rev. 2015, 43, 415-424.

47. Katiraei, F.; Iravani, R.; Hatziargyriou, N.; Dimeas, A. Microgrids management. IEEE Power Energy Mag. 2008, 6, 54-65.

48. Kumar, D. Zare, F.; Ghosh, A. DC microgrid technology: System architectures, AC grid interfaces, grounding schemes, power quality, communication networks, applications, and standardizations aspects. IEEE Access 2017, 5, 12230-12256.

49. Zahira, R.; Sheshathri, P.; Shafiullah, M.S.; Prasad, V.; Vishnu, S. Technical Investigation on Microgrid and Power Quality Impact. Int. J. Scient. Eng. Res. 2014, 5, 183-187.

50. Ali, A.; Li, W.; Hussain, R.; He, X.; Williams, B.W.; Memon, A.H. Overview of current microgrid policies, incentives and barriers in the European Union, United States and China. Sustainability 2017, 9, 1146.

51. Guerrero, J.M.; Vásquez, J.C.; Matas, J.; Castilla, M.; de Vicuña, L.G. Control strategy for flexible microgrid based on parallel line-interactive UPS systems. IEEE Trans. Ind. Electron. 2008, 56, 726-736.

52. Akinyele, D.; Belikov, J.; Levron, Y. Challenges of microgrids in remote communities: A STEEP model application. Energies 2018, 11, 432.

53. Dragicevic, T. Vasquez, J. C. Guerrero, J. M.; Skrlec, D. Advanced LVDC Electrical Power Architectures and Microgrids: A step toward a new generation of power distribution networks. IEEE Electrif. Mag. 2014, 2, $54-65$.

54. Guerrero, J.M.; Loh, P.C.; Lee, T.L.; Chandorkar, M. Advanced control architectures for intelligent microgrids-part II: Power quality energy storage. IEEE Trans. Ind. Electron. 2013, 60, 1254-1262.

55. Zia, M.F.; Elbouchikhi, E.; Benbouzid, M. Microgrids energy management systems: A critical review on methods, solutions, and prospects. Appl. Energy 2018, 222, 1033-1055. [CrossRef]

56. Yolda, Y.; Önen, A.; Muyeen, S.M.; Vasilakos, A.V.; Alan, I. Enhancing smart grid with microgrids: Challenges and opportunities. Renew. Sustain. Energy Rev. 2017, 72, 205-214. [CrossRef]

57. Ustun, T.S.; Ozansoy, C.; Zayegh, A. Recent developments in microgrids and example cases around the world: A review. Renew. Sustain. Energy Rev. 2011, 15, 4030-4041. [CrossRef]

58. Hong, B.; Miao, W.; Liu, Z.; Wang, L. Architecture and Functions of Micro-grid Energy Management System for the Smart Distribution Network Application. Energy Procedia 2018, 145, 478-483. [CrossRef]

59. Logenthiran, T.; Srinivasan, D.; Khambadkone, A.M.; Aung, H.N. Multiagent system for real-time operation of a microgrid in real-time digital simulator. IEEE Trans. Smart Grid 2012, 3, 925-933. [CrossRef]

60. Hossain, M.A.; Pota, H.R.; Issa, W.; Hossain, M.J. Overview of AC microgrid controls with inverter-interfaced generations. Energies 2017, 10, 1300. [CrossRef]

61. Zerhouni, F.Z.; Zerhouni, M.H.; Zegrar, M.; Benmessaoud, M.T.; Stambouli, A.B.; Midoun, A. Proposed methods to increase the output efficiency of a photovoltaic (PV) system. Acta Polytech. Hungarica 2010, 7, $55-70$.

62. Justo, J.J.; Mwasilu, F.; Lee, J.; Jung, J.-W. AC-microgrids versus DC-microgrids with distributed energy resources: A review. Renew. Sustain. Energy Rev. 2013, 24, 387-405. [CrossRef]

63. Nasir, M.; Jin, Z.; Khan, H.A.; Zaffar, N.A.; Vasquez, J.C.; Guerrero, J.M. A Decentralized Control Architecture Applied to DC Nanogrid Clusters for Rural Electrification in Developing Regions. IEEE Trans. Power Electron. 2019, 34, 1773-1785. [CrossRef]

64. Winkler, H. Renewable energy policy in South Africa: Policy options for renewable electricity. Energy Policy 2005, 33, 27-38. [CrossRef]

65. Fagarasan, I.; Stamatescu, I.; Arghira, N.; Hossu, D.; Hossu, A.; Iliescu, S.S. Control Techniques and Strategies for Microgrids: Towards an Intelligent Control. In Proceedings of the 21st International Conference on Control Systems and Computer Science (CSCS), Bucharest, Romania, 29-30 May 2017, pp. 630-635.

66. Lede, A.M.R.; Molina, M.G.; Martinez, M.; Mercado, P.E. Microgrid architectures for distributed generation: A brief review. In Proceedings of the IEEE PES Innovative Smart Grid Technologies Conference-Latin America (ISGT Latin America), Quito, Ecuador, 20-22 September 2017; pp. 1-6. 
67. Wu, P.; Huang, W.; Tai, N.; Liang, S. A novel design of architecture and control for multiple microgrids with hybrid AC/DC connection. Appl. Energy 2018, 210, 1002-1016. [CrossRef]

68. Kazmi, S.A.A.; Hasan, S.F.; Shin, D.R. Analyzing the integration of Distributed Generation into smart grids. In Proceedings of the 2015 IEEE 10th Conference on Industrial Electronics and Applications (ICIEA), Auckland, New Zealand, 15-17 June 2015; pp. 762-766.

69. Ahmed, M.A.; Kang, Y.C.; Kim, Y.C. Communication network architectures for smart-house with renewable energy resources. Energies 2015, 8, 8716-8735. [CrossRef]

70. Gunasekaran, M. Mohamed Ismail, H. Chokkalingam, B. Mihet-Popa, L.; Padmanaban, S. Energy management strategy for rural communities: DC micro grid power system structure with maximum penetration of renewable energy sources. Appl. Sci. 2018, 8, 585. [CrossRef]

71. Satish, B.; Thamilmaran, A. Control of Microgrid-A Review. In Proceedings of the 2014 International Conference on Advances in Green Energy (ICAGE), Thiruvananthapuram, India, 17-18 December 2014; pp. 18-25.

72. Piagi, P.; Lasseter, R.H. Autonomous control of microgrids. In Proceedings of the 2006 IEEE Power Engineering Society General Meeting, Montreal, QC, Canada, 18-22 June 2006; pp. 8-12.

73. Che, L.; Shahidehpour, M. DC microgrids: Economic operation and enhancement of resilience by hierarchical control. IEEE Trans. Smart Grid 2014, 5, 2517-2526.

74. Lu, X.; Guerrero, J.M.; Sun, K.; Vasquez, J.C. An improved droop control method for DC microgrids based on low bandwidth communication with DC bus voltage restoration and enhanced current sharing accuracy. IEEE Trans. Power Electron. 2013, 29, 1800-1812. [CrossRef]

75. Shahidehpour, M.; Khodayar, M. Cutting campus energy costs with hierarchical control: The economical and reliable operation of a microgrid. IEEE Electrif. Mag. 2013, 1, 40-56. [CrossRef]

76. Che, L.; Khodayar, M.; Shahidehpour, M. Only connect: Microgrids for distribution system restoration. IEEE Power Energy Mag. 2013, 12, 70-81.

77. Guerrero, J.M.; Matas, J.; de Vicuna, L.G.; Castilla, M.; Miret, J. Decentralized control for parallel operation of distributed generation inverters using resistive output impedance. IEEE Trans. Ind. Electron. 2007, 54, 994-1004. [CrossRef]

78. Balog, R.S.; Krein, P.T. Bus selection in multibus DC microgrids. IEEE Trans. Power Electron. 2010, 26, 860-867. [CrossRef]

79. Rocabert, J.; Luna, A.; Blaabjerg, F.; Rodriguez, P. Control of power converters in AC microgrids. IEEE Trans. Power Electron. 2012, 27, 4734-4749. [CrossRef]

80. Lund, H. Large-scale integration of wind power into different energy systems. Energy 2005, 30, $2402-2412$. [CrossRef]

81. Dallinger, D.; Wietschel, M. Grid integration of intermittent renewable energy sources using price-responsive plug-in electric vehicles. Renew. Sustain. Energy Rev. 2012, 16, 3370-3382. [CrossRef]

82. Viral, R.; Khatod, D.K. Optimal planning of distributed generation systems in distribution system: A review. Renew. Sustain. Energy Rev. 2012, 16, 5146-5165. [CrossRef]

83. Gyawali, N.; Ohsawa, Y.; Yamamoto, O. Power management of double-fed induction generator-based wind power system with integrated smart energy storage having superconducting magnetic energy storage/fuel-cell/electrolyser. IET Renew. Power Gener. 2011, 5, 407-421. [CrossRef]

84. Vandoorn, T.L.; Meersman, B.; De Kooning, J.D.M.; Vandevelde, L. Analogy between conventional grid control and islanded microgrid control based on a global DC-link voltage droop. IEEE Trans. Power Deliv. 2012, 27, 1405-1414. [CrossRef]

85. Zayandehroodi, H.; Mohamed, A.; Shareef, H.; Mohammadjafari, M. Distributed generator and their effects on distribution system protection performance. Aust. J. Basic Appl. Sci. 2011, 5, 398-405.

86. Giglmayr, S.; Brent, A.C.; Gauché, P.; Fechner, H. Utility-scale PV power and energy supply outlook for South Africa in 2015. Renew. Energy 2015, 83, 779-785. [CrossRef]

87. Msimanga, B.; Sebitosi, A.B. South Africa's non-policy driven options for renewable energy development. Renew. Energy 2014, 69, 420-427. [CrossRef]

88. Naicker, P.; Thopil, G.A. A framework for sustainable utility scale renewable energy selection in South Africa. J. Clean. Prod. 2019, 224, 637-650. [CrossRef]

89. Todd, F. Profiling Four Key Solar Farms and Projects in South Africa. 2019. Available online: https://mail. yahoo.com/d/folders/1/messages/ACWiEUZXjU-kXpNCpQdyQCrpIkc (accessed on 27 April 2020). 
90. Long, N.; Steinberger, K. Renewable Energy Is Key to Fighting Climate Change. 2016. Available online: https:/ / www.nrdc.org/experts/noah-long/renewable-energy-key-fighting-climate-change (accessed on 18 March 2020).

91. Patel, H.; Chowdhury, S. Review of technical and economic challenges for implementing rural microgrids in South Africa. In Proceedings of the 2015 IEEE Eindhoven PowerTech, Eindhoven, The Netherlands, 29 June-2 July 2015; pp. 1-6.

92. Graber, S.; Narayanan, T.; Alfaro, J.; Palit, D. Solar microgrids in rural India: Consumers' willingness to pay for attributes of electricity. Energy Sustain. Dev. 2018, 42, 32-43. [CrossRef]

93. Bullich-Massagué, E.; Diaz-González, F.; Aragüés-Peñalba, M.; Girbau-Llistuella, F.; Olivella-Rosell, P.; Sumper, A. Microgrid clustering architectures. Appl. Energy 2018, 212, 340-361. [CrossRef]

94. Maphosa, C.; Bhebhe, S. Digital literacy: A must for open distance and e-learning (ODEL) students. Eur. J. Educ. Stud. 2019, 5. [CrossRef]

95. Department of Energy. Energy Advocacy Newsletter. 2015. Available online: http:/ /www.energy.gov.za (accessed on 18 March 2020).

96. Department of Energy. Integrated Resource Plan for Electricity 2010-2030, rev.2, Final Report. 2011. Available online: http:/ / www.energy.gov.za/IRP2010_2030_Final_Report.pdf (accessed on 18 March 2020).

97. International Renewable Energy Agency (IRENA). Renewable Energy Technologies: Cost Analysis Series Wind Power. Renew. Energy 2012, 1, 1-64.

98. International Renewable Energy Agency (IRENA). Renewable Energy Technologies: Cost Analysis Series. Green Energy Technol. 2014, 1, 1-45.

99. Renewable Energy. Facts and Futures the energy future we want. Renew. Energy Facts Futures 2017, 6, 1-44.

100. Unwin, J. Solar Power in South Africa: A Look at the Country's Solar Plants. 2019. Available online: https:/ / www.power-technology.com/features/solar-power-south-africa/ (accessed on 18 March 2020).

101. Pallett, K. The Robben Island Solar Microgrid Shows the Power of Solar PV and Batteries. 2017. Available online: https:/ / sola.africa/news/robben-island-solar-microgrid-power-of-solar-pv-andbatteries / (accessed on 25 February 2020).

102. Beck, F; Martinot, E. Renewable Energy Policies and Barriers. 2016. Available online: http:/ /www.martinot. info/Beck_Martinot_AP.pdf (accessed on 18 March 2020).

103. Department of Energy. State of Renewable Energy in South Africa. 2018; pp. 1-196. Available online: http: / / www.energy.gov.za / files/media/Pub /2017-State-of-Renewable-Energy-in-South-Africa.pdf (accessed on 18 March 2020).

104. Menanteau, P.; Finon, D.; Lamy, M.L. Prices versus quantities: Choosing policies for promoting the development of renewable energy. Energy Policy 2003, 31, 799-812. [CrossRef]

105. Winkler, H. Cleaner energy cooler climate: Developing sustainable energy solutions for South Africa. 2011. Available online: http:/ / repository.hsrc.ac.za (accessed on 18 March 2020).

106. Deloitte. The Economic Impact of Electricity Price Increases on Various Sectors of the South African Economy. 2012. Available online: http:/ / www.eskom.co.za (accessed on 18 March 2020).

107. Department of Minerals and Energy. White Paper on Renewable Energy. 2003. Available online: https://unfccc.int/files/meetings/seminar/application/pdf/sem_sup1_south_africa.pdf (accessed on 18 March 2020).

108. Darroll, L. Harvesting the wind: Eskom researches wind energy. Afr. Energy J. 2001, 3, 17-19.

109. Davidson, O.; Winkler, H. South Africa's Energy Future: Visions, driving Factors and Sustainable Development Indicators. 2006. Available online: http:/ / www.erc.uct.ac.za (accessed on 18 March 2020).

110. Eskom. Pricing Methodology. 2016. Available online: http:/ / www.eskom.co.za (accessed on 18 March 2020).

111. Ergon Energy. Long Run Marginal Cost: Considerations in Developing Network Tariffs. 2015. Available online: https: / / docplayer.net (accessed on 18 March 2020).

112. National Energy Regulatory of South Africa (NERSA). Multi-Year Price Determination Methodology. 2011. Available online: http:/ / www.nersa.org.za (accessed on 18 March 2020).

(C) 2020 by the authors. Licensee MDPI, Basel, Switzerland. This article is an open access article distributed under the terms and conditions of the Creative Commons Attribution (CC BY) license (http://creativecommons.org/licenses/by/4.0/). 